\title{
Family Support as a Factor in Cultural Adjustment
}

\author{
Pei-Chen (Chiu-Yi/Joy) Lee
}

\begin{abstract}
Following the growing worldwide competition and internationalisation of globe markets, international expatriates' assignments are become more and more essential to successful worldwide development for many multinational corporations. Therefore, expatriates can become an important human resource to international enterprises or multinational operations. Especially, investigating the influential factors as family support of expatriate adjustment is significant for several reasons. Firstly, failure of expatriate adjustment may cause premature return from overseas assignments, which may be very costly financially for international enterprises. Secondly, failure to accomplish the plan of the assignment is as harmful to the expatriate as it is to the parent and host companies. Inability of an expatriate to complete the assignment is likely to damage his or her self-esteem, and self-confidence, and cause a loss of prestige among co-workers. Thirdly, an unsuccessful period of expatriation is likely to decrease both the subsequent commitment to the parent company.
\end{abstract}

Therefore, to facilitate business expatriates adjustment to an overseas environment and to enable them to work effectively, Multinational Corporations (MNCs) need to recognise the expatriates' family support factor to affect cross-cultural adjustment. The main purpose of this study involves utilising previous researcher Lee's (2002) questionnaire to investigate the relationship between the family support and cross-cultural adjustment of Taiwanese Banks' expatriates assigned to America, and this study employed same questionnaire to examine the relationship between the family and cross-cultural adjustment of Taiwanese expatriates in several different industries assigned to Mainland China. Also, the empirical outcomes were compared between Taiwanese expatriates located in Mainland China and United States. In examining the significant degree of Taiwanese expatriates assigned to Mainland China, the instrument was a questionnaire survey conducted to this study. The variables of interest were measured using items Likert-type questions, and those items are divided into seven categories. Data collected from 353 participants who have experience of a posting to Mainland China for international assignments. Multiple regression and correlation were employed to analyse data.

The statistical results of this study were compared Lee's (2002) research that associated with Taiwanese banking expatriates in United States. Both studies indicated that the expatriates' family support factor to affect cross-cultural adjustment without doubt. This article concludes with suggestions for both international enterprises or MNCs and individual expatriate who operate overseas journey in their normal path of business.

\section{Introduction}

Copyright $($ C 2007 Victoria University. This document has been published as part of the Journal of Business Systems, Governance and Ethics in both online and print formats. Educational and non-profit institutions are granted a nonexclusive licence to utilise this document in whole or in part for personal or classroom use without fee, provided that correct attribution and citation are made and this copyright statement is reproduced. Any other usage is prohibited without the express permission of the
As enterprises develop globally, there is a growing challenge to utilise expatriates on international assignments to complete strategically significant tasks (Brewster 1998; Downes and Thomas 1999; Gregersen and Black 1996). Multinational corporations (MNCs) utilise expatriates, not only for reasons of corporate organisation and expertise in critical global markets, but also to smooth the process of 
entry into new markets or to extend international management abilities (Bird and Dunbar 1991; Boyacigiller 1991; Forster 2000; Rosenzweig 1994; Shaffer, Harrison and Gilley 1999). Particularly, previous researchers (Black and Stephens 1989; Harvey 1985) pointed out that the family situation is an important element of expatriate turnover. Expatriate assignments frequently involve either uprooting families for a move to a new country or making expatriates live away from their families, both of which are stressful to the expatriates and their families. There is a need to look beyond individual influences and to consider job, environment, and family-related factors that would affect expatriate success. Family considerations are frequently mentioned. The presence of family-related problems always elicits more resistance to leaving, but once in the host country it also has a significant effect the desire to return early. Family support practices are often critical during expatriation in order to facilitate the achievement of the objectives of an assignment, so, family support definitely is a significant factor related to adjustment (Caligiuri 1997; Caligiuri et al. 1998; Harvey 1985; Shaffer, Harrison, Gilley, and Luk 2001; Tung 1987).

Therefore, investigating the influential factors as family support of expatriate adjustment is significant for several reasons. First, failure of expatriate adjustment may cause premature return from overseas assignments, which may be very costly financially for international enterprises. In addition, nonfinancial costs of failure, which include damage to the reputation of enterprises, lost business opportunities and lost market or competitive share (Black and Gregersen 1991; Coperland and Griggas 1985; Naumann 1992). Second, failure to accomplish the plan of the assignment is as harmful to the expatriate as it is to the parent and host companies. Inability of an expatriate to complete the assignment is likely to damage his or her self-esteem, and self-confidence, and cause a loss of prestige among coworkers (Mendenhall and Oddou 1985; Tung 1987). Third, an unsuccessful period of expatriation is likely to decrease both the subsequent commitment to the parent company (Naumann 1993) and job performance upon repatriation (Adler 1981). Fourth, an expatriate failure will have an adverse impact on the decision of qualified expatriates to accept overseas posts (Stroh 1995). Nowadays, despite these negative possibilities, those influential factors still exist, nevertheless, following the increasing investment; many more people volunteer to develop their careers in Mainland China for longer periods. The recent growth of international business has guided enterprises to examine more closely their policies for transferring employees from one country to another (Aryee and Stone 1996; Black, Gregersen and Mendenhall 1992). Without proper international human resource management, the advantages of overseas operations may not be fully realised. Yet in Taiwan, very few studies concerning expatriate problems have been conducted (Huang et al. 2000). Therefore, this article investigated the relationship between family support and cross-cultural adjustment based on four theories as following. These four theories which have directed this research on international expatriate adjustment are: Lysgaard's (1995) u-curve theory of adjustment and the cross-cultural cycle of Havelock (1963), Conner (1993), and Zakaria (2000); Mendenhall and Oddou's (1985) dimensions of cross-cultural acculturation; and Black, Mendenhall and Oddou's (1991) an integration of multiple theoretical perspectives.

\section{Literature Review}

In this article investigated the relationship between family support factor and cross-cultural adjustment, therefore, the literature review will included family support factor and cross-cultural adjustment in this section.

\section{Family Support Factor}

International enterprises that have a system of Human Resource practices of careful planning of an assignment's purpose, selection of the candidate to match the purpose, compensation to suit achievement of the objectives of the assignment, and training and development to enable the assignee to effectively carry out the assignment, are also likely to deal with the assignee's family system. This is because family support practices are often critical during expatriation in order to facilitate the achievement of an assignment's objectives. A survey conducted by Windham International and the 
National Foreign Trade Council (1999), revealed that a large number of international assignments are turned down or interrupted because of spouse and family issues. It seems, nevertheless, that much of the research about the development of international expatriates almost makes them appear as isolated individuals without spouses, families, or friends. In fact, the procedure of posting expatriates to an international location often involves the family of the expatriate. In a longitudinal study of families on international assignments Caligiuri et al. (1998) declared that family characteristics, such as support, were significantly connected to the expatriate's adjustment to the work assignment. It is therefore this study proposed that the family support factor can potentially influence expatriate adjustment.

An increasing number of researchers is explaining the role of family variables in the adjustment of expatriates. Nevertheless, most expatriates still have obstacles of family responsibilities. Approximately 80 percent of international assignees are accompanied by a spouse, children or both (Black and Gregersen 1991; Guzzo, Noonan and Elron 1994; Stroh, Dennis and Cramer 1994). Therefore, it is essential to investigate and gain further understanding of the cross-cultural adjustment issue associated with the family or spouse. The family related factor perhaps will achieve success in international expatriations due to the fact that family support assists expatriates to enhance their ability to manage cultural dissimilarity and work challenges in their assignment. Besides, it may increase the expatriate's appreciation of the host country and its culture, and lessen the duration of the expatriate's adjustment to the overseas assignment.

\section{Cross-cultural Adjustment}

Generally, cross-cultural adjustment is defined as the process of adaptation to living and working in a foreign culture. It is the perceived degree of psychological comfort and familiarity a person has with the new host culture (Black, 1988; Mendenhall and oddou, 1987). Several researchers have highlighted factors affecting the process of adjustment. For example, Black, Mendenhall and Oddou (1991) identified anticipatory (before-leaving) and in-country (post-arrival) factors. In addition, they noted work, interactions and general adjustment as three levels of adjustment. Feldman and Tompson (1993) identified six sets of factors: demographic variables; the extent of 'internationalness' of the job change; job characteristics variables; amount of organisation support vis a vis assistance and career development; degree of difference between successive job assignments; and types of individual coping strategies. It is possible to classify factors affecting cross-cultural adjustment into two broad types; extrinsic (those relating to the organisation and environment) and intrinsic factors (those relating to the characteristics, psychological and physical, of the individual. Many studies have found that the crucial problem for the expatriate is that adaptation to the unfamiliar culture than with their professional expertise (eg. Aahad and Osman-Gani, 2000; Dowling et al., 1999; McEnery and DesHarnais, 1990; Osland, 1995). Successful adaptation and cultural adjustment not only directly influence expatriates performance but also lead to corporate success in the international stage.

\section{Methodology}

In order to investigate the family support of Taiwanese expatriates adjustment in Mainland China, the study was adopted quantitative research approach, where the quantitative research approach will then be employed to test the hypotheses.

\section{The Research Sample}

The target population of this study was 1,786 Taiwanese manufacturing firms located in Shanghai. Shanghai is the most developed city of east China and many Taiwanese investors set up their manufacturing company in here. This study used a stratified sampling procedure based on type of industry to select the sample. There are 20 different categories of industries such as food industry, plastics industry, cement industry, spinning and weaving, electric machinery, electric equipment and so on included in these 1,786 firms. Ten companies were selected from each industry by using a random 
numbers table. Therefore, there a total of 200 firms were selected from the address book that is issued by the Straits Exchange Foundation of Taiwan. Non-response was managed by replacement. In this study, the respondents targeted are one expatriate in the each firm.

Due to the employees in each firm can not be calculated definitely, therefore, the author selected six employees from each firm, total of 1200 questionnaires initially mailed to Taiwanese business expatriates in Shanghai and followed-up by e-mail. Total responses were 353, but there were 22 invalid questionnaires. As a result, total response 353 minus the invalid questionnaires 22; therefore, 331 returned surveys were usable. The percentage of valid questionnaires was 27.58 percent. Table 1 also showed the Standard Deviation of family support was 0.3534 .

\section{Statistics Analysis}

All of statistical data analyses were performed using SPSS (Statistical Package for Social Science) for Windows. The analysis used Correlation Coefficient; Descriptive statistics methods were used to describe the sample and inferential statistics to draw conclusions about the theoretical model.

\section{Correlation Coefficient}

Correlation coefficients were computed between the family support and cross-cultural adjustment. The correlation coefficient was used to describe directions and strengths between the independent variable and the dependent variable.

\section{Research Results}

This section of the study, through regression analysis investigated the influence of family support on cross-cultural adjustment through the stepwise method.

Because stepwise regression was requested, SPSS first investigated a model with the correlated independent variable family support, as demonstrated in Table 2. It also revealed that the partial correlation for family support was 0.414 , In effect, independent variable as family support was significant for explaining the cross-cultural adjustment model. The bi-variate correlation between family support and cross-cultural adjustment was positive. At the same time, the independent variable was statistically significant as revealed in Table 1 and Table 2 below: Family Support $(\mathrm{P}=0.000<0.05)$. This appeared to verify that the practical predictor in this study for cross-cultural adjustment was family support. It accounted for 28.94 percent $\left(0.538^{2}\right)$ of the variance of cross-cultural adjustment.

Table 1: Correlations

\begin{tabular}{|c|c|c|c|}
\hline & & Cross-cultural Adjustment & Family Support \\
\hline $\begin{array}{c}\text { Pearson } \\
\text { Correlation }\end{array}$ & Cross-cultural Adjustment & 1.000 & 0.538 \\
\hline & Family Support & 0.538 & 1.000 \\
\hline Sig. (1-tailed) & Cross-cultural Adjustment &. & .000 \\
\hline & Family Support & .000 &. \\
\hline $\mathrm{N}$ & Family Support & 331 & 331 \\
\hline
\end{tabular}

Table 2: Coefficients of Proposed Model

\begin{tabular}{|c|r|c|c|c|c|c|c|}
\hline & \multicolumn{2}{|c|}{$\begin{array}{c}\text { Un-standardised } \\
\text { Coefficients }\end{array}$} & $\begin{array}{c}\text { Standardised } \\
\text { Coefficients }\end{array}$ & & & \multicolumn{2}{|c|}{$\begin{array}{c}95 \% \text { Confidence } \\
\text { Interval for B }\end{array}$} \\
\hline Model & B & Std. Error & Beta & $\mathrm{t}$ & Sig. & $\begin{array}{c}\text { Lower } \\
\text { Bound }\end{array}$ & $\begin{array}{c}\text { Upper } \\
\text { Bound }\end{array}$ \\
\hline Constant & -3.860 & .506 & & -7.633 & .000 & -4.855 & -2.865 \\
\hline $\begin{array}{l}\text { Family } \\
\text { Support }\end{array}$ & 0.902 & 0.110 & 0.318 & 8.191 & 0.000 & 0.686 & 1.119 \\
\hline
\end{tabular}




\begin{tabular}{|c|c|c|c|}
\hline & \multicolumn{3}{|c|}{ Correlations } \\
\hline Model & Zero-Order & Partial & Part \\
\hline Family Support & 0.538 & 0.414 & 0.292 \\
\hline
\end{tabular}

Note: a Dependent Variable: CAA(Cross-cultural Adjustment)

\section{Discussion and Comparison}

The results of this study were also compared with Lee's (2002) research shown in Table 4. Results were quite not different between Taiwanese located in the United State and Mainland China. In this section, independent variable which was significant in the present study: family support was statistically significant, and the statistical result of Taiwanese expatriates assigned to Mainland China was compared with the Taiwanese expatriates located in the United States (Lee 2002) as shown in Table 3 below.

Table 3: The Significance of the Relationship of Independent Variable to Adjust In Mainland China and the United States

\begin{tabular}{|c|c|c|}
\hline \multicolumn{3}{|c|}{$\begin{array}{l}\text { The Significance of the Relationship of Independent Variable to Adjust in Mainland } \\
\text { China and the U.S. }\end{array}$} \\
\hline & Mainland China & United States * \\
\hline Family Support & Significant & Significant \\
\hline
\end{tabular}

According to the statistical analysis in this study the adjustment of the expatriate's family support was positively correlated to the adjustment process of the expatriate. The findings definitely suggest that family support was a key element in the ability to adjust to the overseas assignment. This result is consistent with past research (Black and Gregersen 1991; Black and Stephens 1989; Fukuda and Chu 1994; Schneider and Asakawa 1995; Caligiuri et al. 1998) that found that family support was significantly related to the expatriate's ability to adjust overseas. The result also indicated that expatriate adjustment is not a unitary phenomenon. Clearly family issues, involving the spouse/partner or family members are one of the key problem are as faced by Taiwanese expatriates. To overcome the family support issue, this study suggests that Taiwanese headquarters may help their expatriates by encouraging expatriates' families to accompany them to Mainland China.

In contrast to this study, Lee's (2002) published research provided weak evidence (as $r=0.16, p>0.05$ ) for the mediating role of family support on cross-cultural adjustment of Taiwanese expatriates in the United States. Consequently, family support plays an important role affecting cross-cultural adjustment for Taiwanese expatriates assigned to Mainland China. For Taiwanese expatriates placed in the United States the factor of family support was not a very strong issue determinant of cross-cultural adjustment.

\section{Conclusion}

Besides taking up the challenge of new job responsibilities, international expatriates are also normally required to adjust to different living conditions and various other obstacles. Expatriates' international assignments often involve either transferring families to the new country and a foreign environment or involve forcing the expatriate to live away from their families. Both cases put tension on expatriates and their family members. There is a need to look beyond individual influences and to consider the job, environment, and family-related factors that may affect expatriate success. Past research has found that support from family plays an important role in reducing work and non-work conflict. More specifically, spousal support has received a great deal of attention. For instance, higher levels of family emotional and instrumental support were associated with lower levels of family interference with work conflict. That means that spousal support and family support are direct negative predictors of family interference with work conflict. Therefore, family support has been demonstrated to significantly relate negatively to family interference with work conflict. 
In anticipation of such a trend continuing, it is suggested that organisations might be encouraged to implement a career counseling program for the spouses of their expatriates. Alternatively, Taiwanese enterprises could consider paying double salary when spouses or partners sacrifice their own career, to encourage Taiwanese expatriates to succeed in their overseas assignment. Other benefit programs could be developed for Taiwanese expatriates assigned to Mainland China. Perhaps non-accompanied expatriates could be given a ticket for a trip to Mainland China once a year for the whole family.

\section{References}

Aahad, M. and Osman-Gani 2000, 'Developing expatriates for the Asia-Pacific region: A comparative analysis of multinational enterprise managers from five countries across three countries', Human Resource Development Quarterly, Vol.11, No.3, pp213-235.

Adams, G.A. King, L.A. and King, D.W. 1996, 'Relationships of job and family involvement, family social support, and work-family conflict with job and life satisfaction', Journal of Applied Psychology, Vol.18, No.4, pp.411-420.

Adler, N. and Bartholomew, S. 1992, 'Managing Globally Competent People', Academy of Management Executive, Vol. 6: pp.52-65.

Andreason, A.W., 2003 (Spring), 'Expatriate adjustment to foreign assignments', International Journal of Commerce and Management, Vol.13, No.1, pp.42-53.

Answer, 2005, online, Geography of China, reviewed 27 August 2004, http://www.answers.com/topic/china

Arthur, W. and Bennett, W. 1995, 'The international assignee: the relative importance of factors perceived to contribute to success', Personnel Psychology, Vol. 48: pp.99-114.

Berry, J., Poortinga, Y., Segall, M. and Dasen, P. 1993, 'Cross-cultural Psychology, Research and Applications', Cambridge University Press, Cambridge.

Black, J.S. 1988, 'Work role transitions: a study of American expatriate managers in Japan', Journal of International Business Studies, Vol.19: pp.277-294.

Black, J.S. and Gregersen, H.B. 1991, 'The other half of the picture: Antecedents to cross-cultural adjustment for expatriates in Pacific Rim assignments', Journal of International Business Studies, Vol. 22, No.3, pp.461-477.

Black, J. S. and Stephens, G. K. 1989, 'The Influence of the Spouse on American Expatriate Adjustment in Overseas Assignments', Journal of Management, Vol.15, pp.529-544.

Brewster, C. 1991, The Management of Expatriates, London: Kogan Page.

Brewster, C. 1998, 'International HRM: Beyond expatriation', Human Resource Management, Vol.7, No.3, pp.31-42

Caliguri, P.M., Hyland, M.M., Joshi, A., and Bross, A.S. 1998, 'Testing a theoretical model for examining the relationship between family adjustment and expatriates' work adjustment', Journal of Applied Psychology, Vol.83, pp.598-614.

Caligiuri, P.M., Joshi, A. and Lazarova, M. 1999, 'Factors influencing the adjustment of women on global assignments', International Journal of Human Resource Management, Vol10, No.2, pp.163179.

Caplan, G. 1976, 'The family as a support system', in Caplan G, Killilea M.(Eds.), Support Systems and Mutual Help, Grune and Stratton New York.

Chew, J. 2004, 'Managing MNC Expatriates through Crises: A Challenge for International Human Resource Management', Research and Practice in Human Resource Management, Vol.12, No.2, pp.1-30.

Chiang, P.K. 1994, The Economic Development of the Republic of China on Taiwan: Issues and Strategies, Ministry of Economic Affairs, Taipei.

Church, A.T. 1982, 'Sojourner adjustment', Psychological Bulletin, Vol.9, pp. 540-572.

Collidege and D'Angelo, 1994, 'Family issues to shape the professional's future', The CPA Journal, pp.16-21. 
Downes, M. and Thomas A.S. 1999, 'Managing overseas assignments to build organisational knowledge', Human Resource Planning, Vol.22, No.4, pp.33-48.

Downs, M., Thomas, A.S. and Singley, R.B. 2002, 'Predicting expatriate job satisfaction: the role of firm internationalization', Career Development International, Vol.7, No.1, pp.24-36.

Downes, M. and Thomas, A.T. 1997, 'Expatriation and Internationalisation: A Theoretical Linkage', Journal of International Management, December, pp.323-349.

Gregersen, H.B. and Black, J.S. 1990, 'A multifaceted approach to expatriate retention in international assignments', Group and Organizational Studies, Vol.15, No.4, pp.461-85.

Gregersen, H.B. and Black, J.S. 1992, 'Antecedents to commitment to a parent company and a foreign operation', Academy of Management Journal, Vol.35, No.1, pp.65-90.

Harvey, M.G. 1985, 'The executive family: an overlooked variable in international assignment', Columbia Journal of World Business, Vol.20, pp.84-92.

Harvey, M.G. 1996, 'The impact of dual-career families on international relocations', Human Resource Management Review, Vol.5, No.3.

Harvey, M.G. 1997, 'The impact of the dual-career expatriate on international relocation: the trailing spouse', International Journal of Human Resource Management.

Harvey, M.G. 1998, 'Dual-career couples during international relocation: the trailing spouse', International Journal of Human Resource Management, Vol.9, No.2, pp.309-331.

Handler, C. and Lane, I. 1997, 'Career planning and expatriate couples', Human Resource Management Journal, Vol.7, No.3, pp.67-78.

Kanter, R.M., 1977, Work and family in the United States: a critical review and agenda of research policy, Russel Sage Foundation, New York:

Kao, Charng and Chi-Tsung Huang, 1995, 'The Analysis of the Relationship between Taiwan's Investment in Mainland and Cross-Strait Trade', in Kuang-Shen Liao (ed.), The Potential Danger and Opportunity in the Cross-Strait Economic Interaction, Hong Kong University Press, pp. 95120, Hong Kong.

Kao, C. 1992, An empirical study of Taiwan investment on Mainland China, Commonwealth Publishing, Taipei.

Kao, C. 2001, 'The effect on the Taiwanese economy of manufacturing investment in Mainland China in operating locally', Quarterly Publication of Economical Situation and Comment, Vol.7, No.1.

Lee, H.W. 2002, A study of Taiwanese banking expatriates in the United States, Published dissertation of University of Idaho.

Ministry of Economic Affairs (MOEA), 2002, The Investigation Report on the Outward Investment by Manufacturing Industry, Taiwan.

Ministry of Economic Affairs (MOEA) (1997), The Investigation Report on the Outward Investment by Manufacturing Industry (in Chinese), Taiwan.

---- (1998), The Investigation Report on the Outward Investment by Manufacturing Industry (in Chinese).

---- (1999), 'Table A-12 The Growth Rate of the Industrial Output in Major Countries' (in Chinese), http://www.moea.gov.tw/ meco/stat/four/a-12.htm.

---- (2000), 'The Role of Service Industry in Economic Development' (in Chinese), http://www.moea.gov.tw/ meco/paper/issue/15.htm.

Ministry of Finance (MoF) (Taiwan) (1993), Report on the Characteristic Classifications of Tradeable Commodities.

---- (1998), Monthly Statistics of Exports and Imports, December 1998.

Myers, H.E. 1987, 'The China business puzzle', Business Horizons, Vol.30, No.4, pp.25-28.

Shaffer, M.S. and Harrison, D.A. 1995, 'Forgotten partners: developing and testing a model of spouse adjustment to international assignments', Paper presented at the annual meeting of the Academy of Management, Vancouver.

Shaffer, M.S. and Harrison, D.A. 1998, 'Expatriate's psychological withdrawal from international assignments: Work, non-work, and family influences', Personnel Psychology, 51: 87-118. 
Shaffer, M.A., Harrison, D. A., and Gilley, M.A. 1999, 'Dimensions, determinants, and differences in the expatriate adjustment process', Journal of International Business Studies, Vol.30, No.3, pp.557-559.

Shannonhouse, R. 1996, 'Overseas assignment failures', USA Today/International Edition, 8A. Nov.8.

Sheehan, K. B. and McMillan, S. J. 1999, 'Response variation in e-mail surveys: An exploration', Journal of Advertising Research, Vol.39, No.4, pp.45-54.

Shumsky, N.J. 1992, 'Justifying the intercultural training investment', Journal of European Business, Vol.4, pp.38-43.

Smith, C.R. and Still, L.V. 1996, Women in international assignments: the Australian experience, Edith Cown University, Perth.

Windham International, The National Foreign Trade Council and International human resources, 1999, Global Relocation Trends Survey Report. 